\title{
Kondisi Psikologi Siswa SMP dalam Pembelajaran Matematika pada Masa Pandemi Covid-19
}

\author{
Dwi Ratna Wulan ${ }^{1}$, Cita Dwi Rosita ${ }^{2}$, Tri Nopriana ${ }^{3^{*}}$ \\ 1,2,3Pendidikan Matematika, Universitas swadaya Gunung Jati, Cirebon, Indonesia; \\ dwiiratnawulan913@gmail.com ${ }^{1}$; citadwirosita@gmail.com² $^{2}$, riatrinopriana@gmail.com ${ }^{3}$
}

Info Artikel: Dikirim: 24 November 2021; Direvisi: 7 Februari 2021; Diterima: 28 Maret 2021 Cara sitasi: Wulan, D. R., Rosita, C. D., \& Nopriana, T. (2021). Kondisi Psikologi Siswa SMP dalam Pembelajaran Matematika pada Masa Pandemi Covid-19. JNPM (Jurnal Nasional Pendidikan Matematika) 5(1), 51-64.

\begin{abstract}
Abstrak. Pandemi Covid-19 telah berdampak pada bidang pendidikan salah satunya dengan adanya pembelajaran online. Pembelajaran online ini juga berdampak pada psikologi siswa dikarenakan psikologi siswa sangat penting dalam proses belajar mengajar. Maka dari itu peneliti bermaksud untuk mengetahui dan mendeskripsikan psikologi yaitu emosi, keyakinan dan skema diri, minat dan motivasi siswa SMP dalam pembelajaran matematika online. Metode penelitian yang digunakan adalah kualitatif deskriptif dengan subjek sebanyak 32 siswa SMP yang diambil secara acak dari beberapa sekolah di Kota dan Kabupaten Cirebon. Teknik pengumpulan data menggunakan angket psikologi dan wawancara yang dianalisis secara deskriptif. Hasil menunjukkan bahwa rata-rata psikologi siswa sebesar $64 \%$ hal ini berarti secara keseluruhan psikologi siswa termasuk dalam kategori sedang. sedangnya psikologi siswa dipengaruhi oleh faktor yaitu emosi sebesar $63,65 \%$, keyakinan dan skema diri sebesar $60,78 \%$, minat sebesar $61,41 \%$, dan motivasi sebesar $64,69 \%$ yang secara keseluruhan termasuk dalam kategori sedang. Analisis psikologi ini dapat digunakan oleh guru sebagai rancangan guru sebelum mengajar.

Kata Kunci: Psikologi, Covid-19, Pembelajaran Matematika Online.
\end{abstract}

\begin{abstract}
The Covid-19 pandemic has had an impact on the education sector, one of which is through online learning. Online learning also has an impact on student psychology because student psychology is very important in the teaching and learning process. Therefore, the researcher intends to find out and describe psychology, namely emotions, beliefs and self-schemes, interests and motivation of junior high school students in online mathematics learning. The research method used is descriptive qualitative with the subject of 32 junior high school students who were taken randomly from several schools in Cirebon City and Regency. The data collection technique used psychological questionnaires and interviews which were analyzed descriptively. The results showed that the average student psychology was $64 \%$, this means that the overall psychology of students was included in the moderate category, while student psychology is influenced by factors, namely emotion of $63.65 \%$, self-belief and schema of $60.78 \%$, interest of $61.41 \%$, and motivation of $64.69 \%$ which overall are included in the moderate category. This psychological analysis can be used by teachers as a teacher design before teaching.
\end{abstract}

Keywords: Psychology, Covid-19, Online Mathematics Learning.

\section{Pendahuluan}

Pada akhir Desember 2019 kota Wuhan, China telah muncul kasus yang disebabkan oleh virus yang di sebut Covid-19 (Lee, 2020; Supriatna, 2020; 
Yunus, \& Rezki, 2020). Menurut WHO Virus Covid-19 sudah masuk dalam musibah global, tercatat 216 negara di dunia terpapar (Sundari \& Leonard, 2020). Penyebaran virus ini sangat cepat, pada awal Maret 2020 virus Covid19 telah mewabah di Indonesia, terkonfirmasi bahwa 34 provinsi dan 415 kabupaaten/kota terpapar virus Covid-19 (Sundari \& Leonard, 2020). Pandemi Covid-19 telah menyebabkan beberapa gangguan yang luas pada bidang pendidikan, profesi medis dan kesehatan (Ahmed, Allaf \& Elghazaly, 2020; Ahmed, Shehata \& Hassanien, 2020).

Terkait Surat Edaran Nomor 2 Tahun 2020 tentang pencegahan dan penanganan Covid-19 di lingkungan Kemendikbud serta Surat Edaran Nomor 3 Tahun 2020 pencegahan Covid-19 pada satuan pendidikan. Pemerintah memberikan kebijakan untuk pembelajaran dilakukan dirumah dengan melaksanakan pembelajaran online selama masa pademi Covid-19. Namun, pada kenyataannya, pelaksanaan pembelajaran matematika pada masa pandemi masih kurang efektif. Siswa kesulitan menerima pembelajaran matematika saat tatap muka, terlebih lagi saat menghadapi pembelajaran daring. Diperkuat oleh Wiryanto dan Siahaan dalam penelitiannya menjelaskan bahwa dalam pembelajaran online guru dan murid tidak bisa memberikan feedback secara cepat, pemahaman siswa terhadap materi kurang mendalam dan pelajar tidak memiliki motivasi tinggi dan cenderung gagal (Wiryanto, 2020).

Salah satu penyebab siswa sulit menerima pembelajaran yaitu psikologi siswa yang rendah terhadap pembalajaran matematika. Psikologi siswa sangat berpengaruh terhadap pembelajaran matematika, jika psikologi siswa rendah maka siswa sulit menerima materi yang diberikan oleh guru yang juga berpengaruh juga terhadap hasil belajar, motivasi belajar serta prestasi belajar matematika (Siregar \& Nurdiana, 2017; Supardi, Leonard, Suhendri, \& Rismurdiyati, 2015). Maka dari itu psikologi sangat penting bagi pembelajaran matematika. Setiap guru wajib mempelajari psikologi pendidikan agar guru mampu melihat minat, dan kemampuan siswa dalam pembelajaran (Dodi \& Nofri, 2016). Nezhad \& Vahedi (2011) mengungkapkan bahwa pendidikan dan psikologi sangat berhubungan erat, psikologi pendidikan memberikan makna bahwa bukan hanya siswa kelas atas yang memiliki hak untuk belajar, namun setiap individu memilikinya, setiap sekolah wajib memahami psikologi pendidikan dan menjadikan suatu rancangan guru sebelum mengajar.

Berdasarkan pembahasan sebelumnya, peneliti bermaksud untuk menganalisis lebih mendalam psikologi siswa dalam pembelajaran matematika online pada masa pandemi Covid-19. Ada beberapa peneliti 
yang membahas mengenai psikologi siswa di masa pandemi namun belum dibahas untuk semua indikator psikologi. Seperti penelitian lain yang hanya membahas motivasi siswa di masa pandemi (Cahyani, Listiana, \& Larasati, 2020). Oktawirawan (2020) yang hanya membahas kecemasan siswa terhadap pembelajaran di masa pandemi. Penelitian ini akan membahas keseluruhan indikator psikologi siswa di masa pandemi yaitu, emosi, keyakinan dan skema diri, motivasi dan minat (Siregar \& Nurdiana, 2017). Penelitian ini diharapkan dapat dijadikan dasar bagi guru untuk menyusun rencana pembelajaran.

\section{Metode}

Penelitian ini menggunakan metode kualitatif deskriptif. Penelitian ini mengdeskripsikan hasil analisis psikologi siswa SMP yang meliputi: emosi, keyakinan dan skema diri, minat, dan motivasi. Peneliti menyebar angket ke beberapa sekolah dan terdapat sebanyak 32 responden yang mengisi. Maka subjek penelitian ini sebanyak 32 siswa SMP kelas 7 sampai 9 secara acak dari beberapa siswa SMP di kota dan kabupaten Cirebon.

Prosedur yang dilakukan dalam penelitian ini adalah sebagai berikut: (1) menyusun angket, angket yang disusun berdasarkan empat indikator psikologi menurut Siregar \& Nurdiana (2017) yaitu, emosi, keyakinan dan skema diri, motivasi dan minat, (2) penyebaran angket yang dilakukan menggunakan google form kepada 32 siswa SMP di kabupaten/kota Cirebon, (3) analisa angket, (4) penarikan kesimpulan. Angket yang dipakai dalam pengambilan data terdiri dari 40 butir peryataan yang menggunakan Skala Likert dengan alternatif jawaban, yaitu: Sangat Setuju (SS), Setuju (S), Tidak Setuju (TS), dan Sangat Tidak Setuju (STS). Angket psikologi terbagi dalam beberapa kategori pada table 1 .

Tabel 1. Penskoran Nilai Peryataan Angket

\begin{tabular}{ccccc}
\hline Pernyataan & \multicolumn{4}{c}{ Skor } \\
& SS & S & TS & SS \\
\hline Positif & 4 & 3 & 2 & 1 \\
Negatif & 1 & 2 & 3 & 4 \\
\hline
\end{tabular}

Analisis angket psikologi yang digunakan untuk mencari persentase yang dicapai siswa pada saat pembelajaran daring dimasa Covid-19. Menurut Syarifudin (2010:112) dalam penelitiannya menjelaskan cara mengubah skor atau penilaian kedalam bentuk persentase, yaitu dengan rumus:

$$
\%=\frac{\sum X}{\sum \text { Maks }} x 100 \%
$$


Keterangan:

$\begin{array}{ll}\% & : \text { Persentase } \\ \sum X & : \text { Skor } X \text { hitung } \\ \sum \text { Maks } & : \text { Skor maksimal ideal }\end{array}$

Setelah melakukan pencarian persentase masuk kepengkategorian analisis psikologi siswa SMP dalam pembelajaran matematika secara online pada masa Covid-19. Dalam penelitian ini menggunakan cara dari Syarifudin (2010:112) terdapat 5 kategori penilaian, yaitu: "Sangat Tinggi", "Tinggi", "Sedang", "Rendah", dan "Sangat Rendah". Sedangkan untuk pengkategoriannya menggunakan acuan 5 batas normal yaitu seperti dalam tabel 2.

Tabel 2. Rumus Kategori Rentang Norma Penilaian

\begin{tabular}{ccc}
\hline No & Rentang Norma & Kategori \\
\hline 1 & $\mathrm{X} \geq \mathrm{M}+1,5 \mathrm{SD}$ & Sangat Tinggi \\
2 & $\mathrm{M}+0,5 \mathrm{SD} \leq \mathrm{X}<\mathrm{M}+1,5 \mathrm{SD}$ & Tinggi \\
3 & $\mathrm{M}-0,5 \mathrm{SD} \leq \mathrm{X}<\mathrm{M}+0,5 \mathrm{SD}$ & Sedang \\
4 & $\mathrm{M}-1,5 \mathrm{SD} \leq \mathrm{X}<\mathrm{M}-0,5 \mathrm{SD}$ & Rendah \\
5 & $\mathrm{X}<\mathrm{M}-1,5 \mathrm{SD}$ & Sangat Rendah \\
\hline
\end{tabular}

Adapun kategori angket psikologinya pada tabel 3 .

Tabel 3. Kategori Psikologi Siswa

\begin{tabular}{cc}
\hline interval skor & Kategori \\
\hline$X \geq 78.94$ & Sangat Tinggi \\
$68.98 \leq X \geq 78.94$ & Tinggi \\
$59.02 \leq X<68.98$ & Sedang \\
$49.03 \leq X<59.02$ & Rendah \\
$X<49.03$ & Sangat Rendah \\
\hline
\end{tabular}

Adapun kisi-kisi wawancaranya pada tabel 4.

Tabel 4. Kisi-kisi Wawancara

\begin{tabular}{cc}
\hline Indikator Psikologi & \multicolumn{1}{c}{ Pertanyaan } \\
\hline Emosi & $\begin{array}{l}\text { 1. apakah ade senang belajar dirumah? } \\
\text { 2. Apakah ade merasa cemas ketika guru memberikan } \\
\text { tugas matematika secara online? }\end{array}$ \\
Keyakinan & $\begin{array}{l}\text { 3. apakah ade bisa mengerjakan soal matematika yang } \\
\text { diberikan oleh guru? }\end{array}$ \\
dan Skema Diri & 4. apakah ade sering menjawab atau bertanya kepada \\
& guru selama pembelajaran berlangsung? \\
Minat & 5. apakah ade selalu mengikuti pembelajaran matematika \\
& yang guru berikan?".
\end{tabular}




\begin{tabular}{ccc}
\hline Indikator Psikologi & \multicolumn{1}{c}{ Pertanyaan } \\
\hline & 6. & apakah ade selalu mengerjakan tugas yang diberikan \\
& oleh guru?
\end{tabular}

\section{Hasil dan Pembahasan}

Selama masa pandemi Covid-19 pembelajaran jarak jauh dengan melakukan pembelajaran melalui online adalah salah satu solusi yang sangat dianjurkan. Dalam penelitian ini peneliti terlebih dahulu mengamati dan melakukan wawancara terkait pembelajaran online pada masa pendemi Covid-19. Berdasarkan hasil pengamatan sekolah-sekolah sudah banyak menggunakan alternatif media pembelajaran online seperti: video pembelajaran dari youtube, whatsapp, google classroom, zoom, dan lain sebagainya. Berikut adalah hasil wawancara dengan salah satu siswa terkait pembelajaran online.

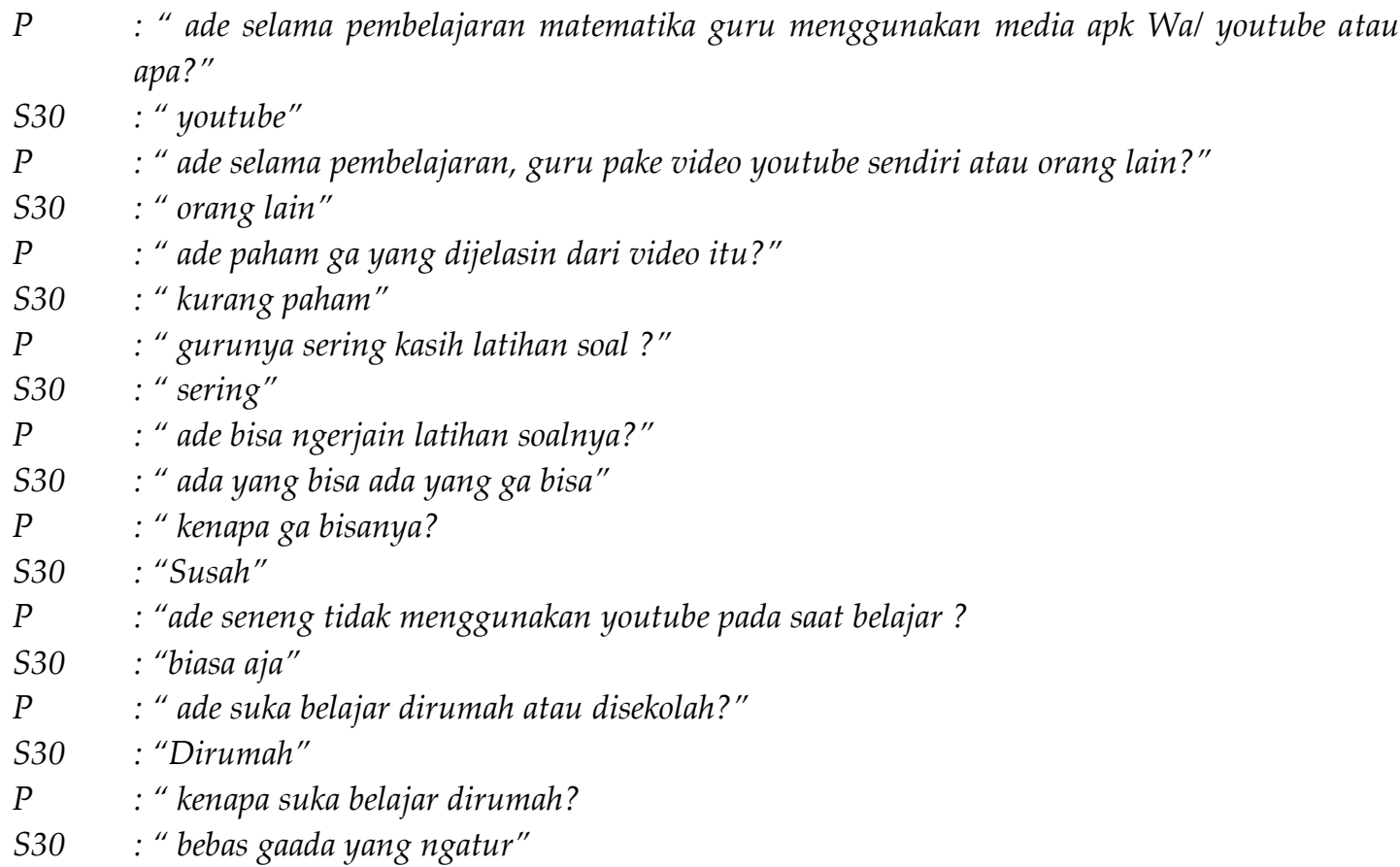

Berdasarkan percakapan peneliti dengan salah satu siswa SMP yang menggunakan media pembelajaran online dari youtube menjelaskan bahwa siswa belajar dengan menggunakan video yang ditayangkan di youtube berdasarkan anjuran dari guru, kemudian guru memberikan latihan soal setelah melihat video tersebut untuk menguji kemampuan siswa dalam materi yang diajarkan, Dalam penelitian ini selain faktor kemampuan berfikir psikologi siswa pun dipengaruhi emosi, keyakinan dan skema diri, minat dan motivasi. 
Data psikologi siswa secara keseluruhan disajikan melalui gambar 1.

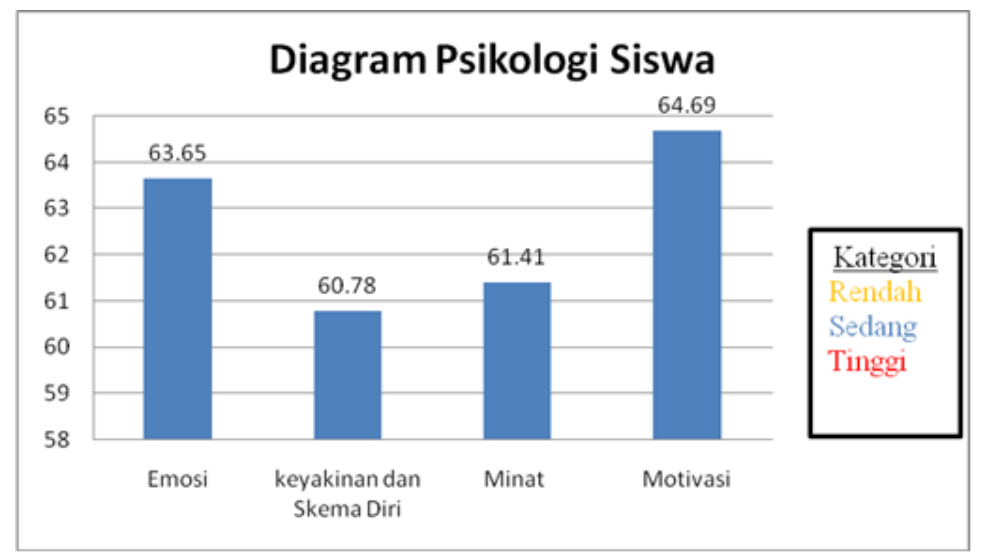

Gambar 1. Diagram Data Psikologi Siswa SMP Secara Keseluruhan dalam Pembelajaran Matematika Secara Online Dimasa Pandemi Covid-19

Gambar 1 menunjukan psikologi siswa SMP dalam pembelajaran matematika pada masa pandemi Covid-19 secara keseluruhan indikator termasuk dalam kategori sedang. Hal ini dapat dikatakan bahwa siswa SMP cukup mampu mengenali dirinya sendiri, mandiri, senang dalam belajar secara online, memiliki keingintahuan yang cukup terhadap pembelajaran matematika, dan lebih berani dalam mengungkapkan pendapat.

Berikut disajikan hasil angket psikologi berdasarkan masing-masing indikator.

\section{Emosi}

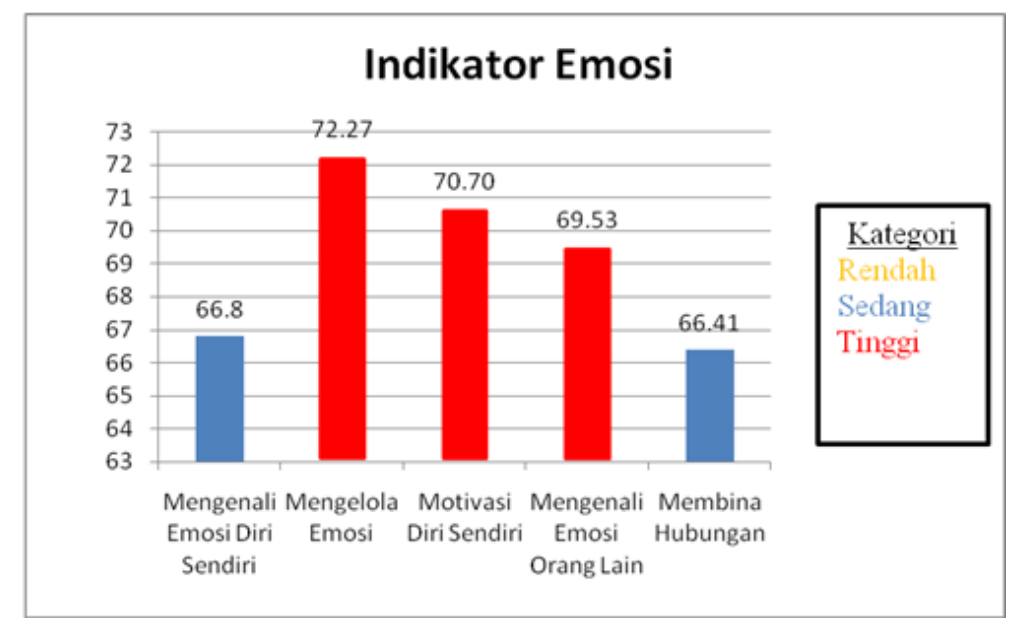

Gambar 2. Diagram Psikologi Siswa Berdasarkan Indikator Emosi

Gambar 2 menunjukan psikologi siswa SMP berdasarkan indikator emosi secara keseluruhan termasuk dalam kategori sedang. Hal ini menunjukan 
bahwa siswa SMP cukup mampu mengontrol perasaannya dan mengenali perasaannya. Dalam kondisi Covid-19 siswa mampu melakukan pembelajaran dengan baik, senang dalam belajar online dan selalu berfikir dalam bertindak. Hal tersebut sesuai dengan indikator mengenali emosi diri sendiri. Dibuktikan dengan hasil wawancara berikut:

P : : "apakah ade senang belajar dirumah?".

Siswa : "Senang, lebih bebas"

P : " Apakah ade merasa cemas ketika guru memberikan tugas matematika secara online?"

Siswa : "biasa aja"

Berdasarkan hasil wawancara menunjukan bahwa siswa senang dalam pembelajaran online dan tidak merasa terbebani dalam pembelajaran matematika secara online.

\section{Keyakinan dan Skema Diri}

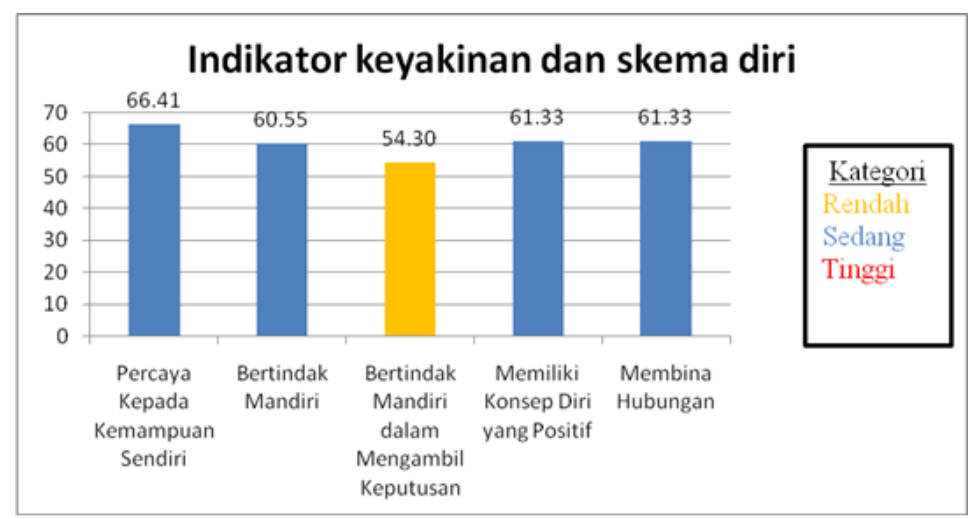

Gambar 3. Psikologi Siswa Berdasarkan Keyakinan dan Skema Diri

Gambar 3 menunjukan bahwa keyakinan dan skema diri adalah faktor kedua dalam psikologi yang termasuk dalam kategori sedang. Sedangnya keyakinan dan skema diri dalam pembelajaran matematika online menunjukan bahwa siswa cukup mampu mengenali kemampuan diri sendiri, memiliki konsep diri yang positif, dan berani mengungkapkan pendapat. Dibuktikan dengan hasil wawancara berikut.

$P \quad$ : apakah ade bisa mengerjakan soal matematika yang diberikan oleh guru?

Siswa : ada yang bisa ada yang engga teh.

$P \quad$ : apakah ade sering menjawab atau bertanya kepada guru selama pembelajaran berlangsung?

Siswa : pernah jawab soal dari ibu tapi seringnya nanya the. 
Berdasarkan hasil wawancara menunjukan bahwa siswa mampu mengenali kemampuannya sendiri dan berani mencoba menyelesaikan permasalahan yang guru berikan.

\section{Minat}

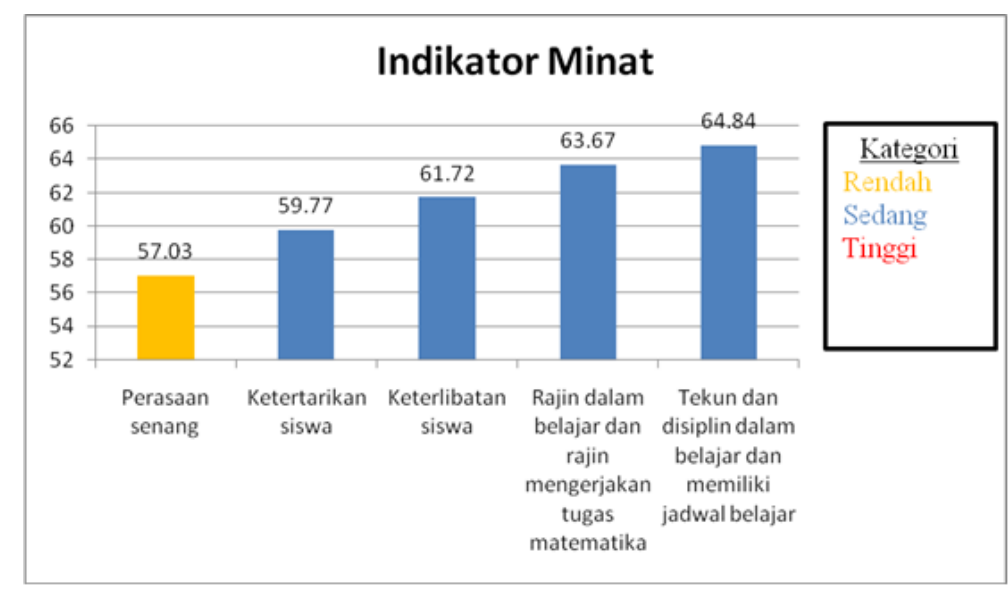

Gambar 3. Psikologi Siswa Berdasarkan Minat

Gambar 3 menunjukan bahwa minat adalah faktor ketiga dari psikologi pendidikan siswa SMP dalam pembelajaran matematika melalui pembelajaran online pada masa pandemi Covid-19 yang secara keseluruhan termasuk dalam kategori sedang. Hal ini menunjukan bahwa siswa memiliki ketertarikan dalam pembelajaran online, cukup aktif dalam pembelajaran online, rajin dalam mengerjakan tugas matematika, tekun, disiplin dalam belajar dan memiliki jadwal belajar. Dibuktikan dengan hasil wawancara berikut:

$P \quad$ : apakah ade selalu mengikuti pembelajaran matematika yang guru berikan?

Siswa : iya teh.

$P \quad$ : apakah ade selalu mengerjakan tugas yang diberikan oleh guru?

Siswa : ngerjain trus the.

Berdasarkan hasil wawancara menunjukan bahwa siswa selalu tekun dalam pembelajaran matematika dan rajin dalam mengerjakan tugas. 


\section{Motivasi}

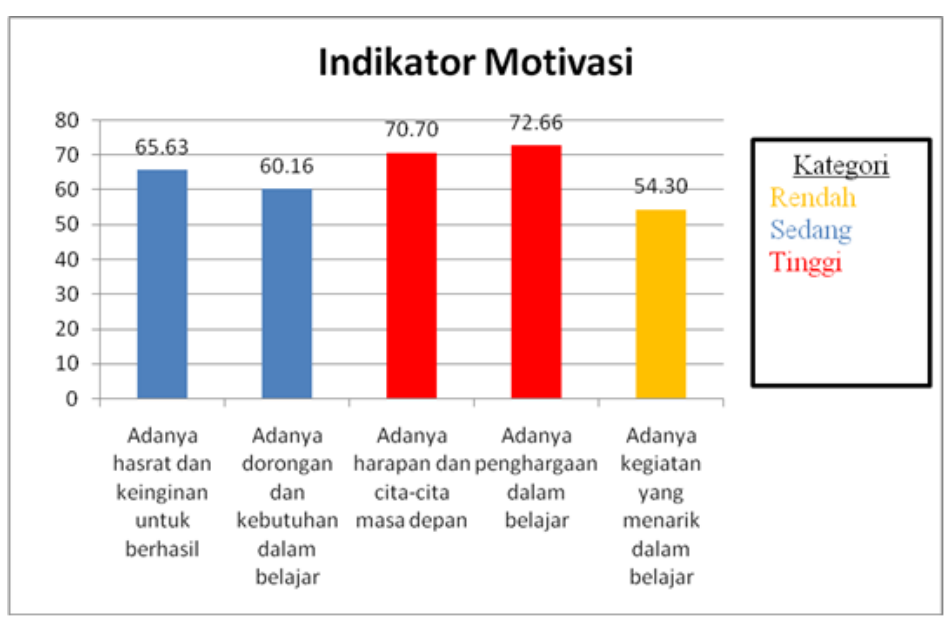

Gambar 4. Psikologi Siswa Berdasarkan Indikator Motivasi

Gambar 4 menunjukan bahwa motivasi adalah indikator keempat dari psikologi pendidikan siswa SMP terhadap pembelajaran matematika melalui pembelajaran online pada masa pandemi Covid-19 yang secara keseluruhan termasuk dalam kategori sedang. Hal ini menunjukan adanya dorongan dan kebutuhan dalam belajar, adanya harapan dan cita-cita masa depan, adanya penghargaan dalam belajar, dan Adanya kegiatan yang menarik dalam belajar. Dibuktikan dengan hasil wawancara berikut:

P : ketika ade salah menjawab soal matematika, apakah ade trus mengerjakan sampai benar?

Siswa : iya teh, nanya trus keguru.

$P \quad$ : apakah ade selalu bertanya ketika tidak mengerti?

Siswa : iya the.

Hasil wawancara menunjukan bahwa siswa memiliki motivasi dalam pembelajaran dan adanya keinginan untuk berhasil. Berdasarkan hasil penelitian menunjukan bahwa siswa masih kesulitan dalam memahami materi matematika pada pembelajaran online yaitu 1) siswa kurang mampu dalam memahami materi yang ditampilkan, 2) siswa masih kesulitan dalam menjawab soal yang diberikan oleh guru, 3) siswa kurang merasa senang dalam pembelajaran. Penelitian ini diperkuat oleh Wiryanto (2020) dalam penelitiannya menjelaskan bahwa dalam pembelajaran online guru dan murid tidak bisa memberikan feedback secara cepat dan pemahaman siswa terhadap materi kurang mendalam. Hal ini berkaitan dengan psikologi siswa dimana siswa kurang bisa memahami materi dan masih kesulitan dalam menjawab soal yang termasuk dalam kemampuan berfikir. Menurut 
Afcariono (2008) kemampuan berfikir diperoleh dari kemampuan siswa dalam menyampaikan pertanyaan dan menjawab soal. Kemampuan berfikir ini merupakan salah satu faktor psikologi. Sejalan dengan hasil penelitian Siregar \& Nurdiana (2017) menjelaskan psikologi pendidikan adalah salah satu cabang ilmu psikologi yang mempelajari ilmu jiwa, psikologi pendidikan meliputi kemampuan berfikir, emosi, keyakinan dan skema diri, minat dan motivasi. Selain itu, menurut Ramdani \& Apriansyah (2018) faktor yang mempengaruhi pemahaman dan berfikir matematik siswa di pengaruhi oleh psikologi siswa.

Psikologi siswa dalam siswa SMP dalam pembelajaran online memperoleh kategori sedang yang artinya siswa cukup mampu mengenali dirinya sendiri, mandiri, senang dalam belajar secara online, memiliki keingintahuan yang cukup terhadap pembelajaran matematika, dan lebih berani dalam mengungkapkan pendapat. Diperkuat oleh Prabowo (2016) sedangnya psikologi menyatakan bahwa siswa cukup mampu menerima dirinya apa adanya, membentuk hubungan yang hangat dengan orang lain dan memiliki kemandirian. Psikologi sendiri memiliki beberapa indikator yaitu emosi, keyakinan dan skema diri, minat, dan motivasi.

Pada indikator emosi, siswa cukup mampu mengontrol perasaannya dan mengenali perasaannya yaitu merasa senang dan tidak terbebani dalam pembelajaran online. Sejalan dengan hasil penelitian Wibawa (2013) dalam penelitiannya menunjukan bahwa siswa sudah bisa mengatur emosi dengan baik dan melakukan kegiatan yang positif. Gusniwati (2015) juga menjelaskan bahwa emosi siswa sangat berpengaruh terhadap meningkatnya penguasaan konsep matematika. Selain itu menurut Wibawa (2013) dalam penelitiannya menjelaskan bahwa indikator mengenali emosi sendiri juga dipengaruhi oleh karakteristik siswa SMP yang sejatinya masih dalam tahap perkembangan mengenal hal-hal baru dan mengahadapi permasalahan yang mulai beragam.

Berdasarkan gambar 2 juga memunculkan fakta yang menarik bahwa siswa bisa mengenali emosi orang lain, namun untuk mengenali emosi diri sendiri masih kurang. penyebab kurangnya siswa dalam mengenal emosinya. Menurut Marpaung (2016) mengenal emosi sendiri dipengaruhi oleh bertambahnya usia, semakin dewasa seseorang dapat lebih baik mengenal emosinya dibandingkan dengan remaja dan anak-anak. Maka siswa yang masih dalam usia remaja masih belum baik dalam mengenal emosinya sendiri. Sedangnya emosi juga dipengaruhi mengenal emosi diri, mengelola emosi, motivasi diri, mengenali emosi orang lain, dan membina hubungan. 
Pada indikator keyakinan dan skema diri, siswa cukup mampu mengenali kemampuan diri sendiri, memiliki konsep diri yang positif, dan berani mengungkapkan pendapat. Hal ini berdasarkan wawancara bahwa siswa ketika tidak bisa maka akan bertanya pada guru. Sejalan dengan penelitian Firman, \& Rahman (2020) dalam penelitiannya mereka menemukan hal menarik yaitu pelajar lebih percaya diri untuk bertanya dan berpendapat dalam forum diskusi. Selain itu kepercayaan diri siswa sangat berhubungan erat terhadap prestasi belajar dan hasil belajar (Rozaini \& Anti, 2017; Nurdianti \& Nurkhin, 2016). Penelitian lain juga menjelaskan bahwa siswa yang kurang dalam pembelajaran matematika disebabkan oleh rendahnya kepercayaan diri, rasa cemas dan siswa yang kepercayaan dirinya kurang akan mengerjakan soal dengan strategi menghapal sehingga ragu dalam mengambil keputusan (Tresnawati, Hidayat, \& Rohaeti, 2017; Wahyuni, $\underline{2014})$.

Berdasarkan gambar 3 juga menghasilkan sebuah fakta yang menarik yaitu siswa percaya kepada kemampuannya sendiri, namun siswa masih kurang bertindak mandiri dalam mengambil keputusan. Yang berarti siswa masih membutuhkan pendapat orang lain dalam mengambil keputusan. Hal ini menunjukan juga bahwa siswa selalu ingin mencari kebenaran atas jawabanya. Hal ini disebabkan oleh penelitian Nafi'ah \& Prasetyo (2015) menjelaskan bahwa siswa dalam mengumpulkan data atau informasi selalu berhati-hati dan melakukan pengulangan dalam mengambil data sampai memperoleh data yang terpercaya.

Pada indikator minat, siswa memiliki ketertarikan dalam pembelajaran online, cukup aktif dalam pembelajaran online, rajin dalam mengerjakan tugas matematika, tekun, disiplin dalam belajar dan memiliki jadwal belajar. Menurut Sabran \& Sabara (2019) dalam pembelajaran daring siswa lebih aktif dikarenakan siswa tidak malu berpendapat. Selain itu minat juga berhubungan dengan prestasi dan hasil belajar. Menurut Apriyanto \& Herlina (2020) dalam pembelajaran daring siswa dapat meningkatkan prestasi belajar akan tetapi minat siswa turun dikarenakan siswa lebih suka tatap muka. Pembelajaran daring yang terlalu lama membuat siswa jenuh dalam pembelajaran online, siswa yang sudah terbiasa berinteraksi dengan teman-temannya kini siswa kehilangan jiwa sosialnya (Purwanto, Prmanono, Asbari, Santoso, Wijayanti, Hyun, \& Putri, 2020). Rendahnya indikator minat juga di pengaruhi oleh strategi guru dalam pembelajaran, jika pembelajaran menyenangkan siswa juga senang mengikuti pembelajaran tersebut. Hal ini juga diperkuat oleh pendapat Marwoto (2014) dalam penelitiannya menjelaskan bahwa strategi guru yang tepat dan bervariasi membuat minat 
belajar siswa menjadi tinggi. Berdasarkan gambar 4 juga memperoleh sebuah fakta menarik bahwa beberapa siswa tekun dan disiplin dalam pembelajaran namun siswa kurang merasa senang. Hal ini menyatakan bahwa siswa yang rajin dan disiplin dalam pembelajaran belum tentu siswa tersebut merasa senang dalam pembelajaran. Sejalan dengan penelitian lain yang menjelaskan kedisiplinan siswa berpengaruh positif terhadap prestasi belajar siswa. Pada indikator motivasi, siswa mempunyai dorongan dan kebutuhan dalam belajar (Wirantasa, 2017; Rusni \& Agustan, 2018). Berdasarkan wawancara juga siswa terus mencoba menjawab soal sampai benar dan bertanya ketika tidak bisa menjawab. Fitriyani, Fauzi \& Sari (2020) menjelaskan bahwa siswa memiliki motivasi dan dorongan yang sangat kuat untuk mendapatkan nilai terbaik dari setiap tugas yang diberikan setelah proses pembelajaran. Keinginan untuk mendapatkan nilai terbaik harus didorong dengan usaha dan kerja keras yang tinggi baik dalam proses kegiatan pembelajaran maupun pada dari saat mengerjakan tugas pembelajaran.

Selain itu, motivasi juga berhubungan erat dengan prestasi belajar. Sesuai dengan penelitian Kamaludin (2017) dalam penelitiannya menjelaskan bahwa motivasi belajar sangat berpengaruh terhadap prestasi belajar, motivasi belajar berbanding lurus dengan prestasi belajar, siswa yang motivasi belajarnya tinggi akan membuat suasana kelas menjadi aktif. Adapun penyebab sedangnya motivasi juga dipengaruhi oleh peran pendidik dalam mengajar. Menurut Werdayanti (2008) dalam penelitiannya menjelaskan bahwa peran guru dalam meningkatkan motivasi siswa lebih besar dari pada fasilitas yang disediakan, motivasi yang tinggi akan membuat siswa termotivasi dalam mengikuti pembelajaran. Sejalan dengan penelitian lain menjelaskan bahwa kreativitas guru dapat meningkatkan motivasi belajar siswa, guru yang kreatif adalah guru yang tau bagamana membuat pembelajaran menjadi menyenangkan (Oktiani, 2017; Herawati, 2017).

\section{Simpulan}

Berdasarkan analisis temuan dan pembahasan pada penelitian ini, dapat disimpulkan bahwa psikologi siswa SMP dalam pembelajaran matematika melalui pembelajaran online pada masa pandemi Covid-19 memperoleh presentase $64 \%$ termasuk dalam kategori sedang. sedangnya psikologi siswa dipengaruhi oleh faktor yaitu emosi, keyakinan dan skema diri, minat, dan motivasi siswa yang secara keseluruhan termasuk dalam kategori sedang. Analisis psikologi ini dapat digunakan oleh guru sebagai rancangan guru sebelum mengajar di pembelajaran online dengan memperhatikan tiap-tiap 
indikator yang mempengaruhi psikologi siswa dalam pembelajaran matematika online agar psikologi siswa dalam pembelajaran online baik.

\section{Daftar Pustaka}

Afcariono, M. (2008). Penerapan pembelajaran berbasis masalah untuk meningkatkan kemampuan berpikir siswa pada mata pelajaran biologi. Jurnal Pendidikan Inovatif, 3(2), 65-68.

Ahmed, S., Shehata, M., \& Hassanien, M. (2020). Emerging Faculty Needs for Enhancing Student Engagement on a Virtual Platform. MedEdPublish, 9.

Ahmed, H., Allaf, M. and Elghazaly, H. (2020). Covid-19 and medical education. The Lancet. Online First. Published: March 23. https://doi.org/10.1016/S1473-3099(20)30226-7

Apriyanto, M. T., \& Herlina, L. (2020). Analisis Prestasi Belajar Matematika pada Masa Pandemi Ditinjau dari Minat Belajar Siswa. Diskusi Panel Nasional Pendidikan Matematika.

Cahyani, A., Listiana, I. D., \& Larasati, S. P. D. (2020). Motivasi Belajar Siswa SMA pada Pembelajaran Daring di Masa Pandemi Covid-19. IQ (Ilmu Al-qur'an): Jurnal Pendidikan Islam, 3(01), 123-140. https://doi.org/10.37542/iq.v3i01.57

Dodi, \& Nofri. (2016). Pentingnya Guru untuk Mempelajari Psikologis Pendidikan. NUSANTARA, 1(1), 59-64.

Firman, F., \& Rahayu, S. (2020). Pembelajaran Online di Tengah Pandemi Covid19. Indonesian Journal of Educational Science (IJES), 2(2), 81-89. https://doi.org/10.31605/ijes.v2i2.659

Fitriyani, Y., Fauzi, I., \& Sari, M. Z. (2020). Motivasi Belajar Mahasiswa Pada Pembelajaran Daring Selama Pandemik Covid-19. Jurnal Kependidikan: Jurnal Hasil Penelitian dan Kajian Kepustakaan di Bidang Pendidikan, Pengajaran dan Pembelajaran, 6(2), 165-175. https://doi.org/10.33394/jk.v6i2.2654

Gusniwati, M. (2015). Pengaruh kecerdasan emosional dan minat belajar terhadap penguasaan konsep matematika siswa SMAN di Kecamatan Kebon jeruk. Formatif: Jurnal Ilmiah Pendidikan MIPA, 5(1), 26-41. https://doi.org/10.30998/formatif.v5i1.165

Herawati, E. (2017). Upaya Meningkatkan Motivasi dan Hasil Belajar Siswa Menggunakan Media Pembelajaran Kartu Domino Matematika pada Materi Pangkat Tak Sebenarnya dan Bentuk Akar Kelas IX SMP Negeri Unggulan Sindang Kabupaten Indramayu. JNPM (Jurnal Nasional Pendidikan Matematika), 1(1), 66-87. https://doi.org/10.33603/jnpm.v1i1.254

Herliandry, L. D., Nurhasanah, N., Suban, M. E., \& Kuswanto, H. (2020). Pembelajaran Pada Masa Pandemi Covid-19. JTP-Jurnal Teknologi Pendidikan,22(1), 65-70. https://doi.org/10.21009/jtp.v22i1.15286

Lee, A. (2020). Wuhan novel coronavirus (COVID-19): why global control is challenging?. Public health, 179, A1. https://doi.org/10.1016/j.puhe.2020.02.001

Kamaludin, M. (2017). Pengaruh Motivasi Belajar Terhadap Prestasi Belajar Matematika dan Strategi untuk Mengingkatkannya. Prosiding Seminar Pendidikan Matematika UNY, 455460.

Oktiani, I. (2017). Kreativitas Guru dalam Meningkatkan Motivasi Belajar Peserta Didik. Jurnal Kependidikan, 5(2), 216-232. https://doi.org/10.24090/jk.v5i2.1939

Prabowo, A. (2016). Kesejahteraan Psikologis Remaja Di Sekolah. Jurnal Ilmiah Psikologi Terapan, 4(2), 246-260. https://doi.org/10.22219/jipt.v5i2.4857

Purwanto, A., Pramono, R., Asbari, M., Santoso, P. B., Wijayanti, L. M., Hyun, C. C., Putri, R. S., (2020). Studi Eksploratif Dampak Pandemi COVID-19 Terhadap Proses Pembelajaran Online di Sekolah Dasar. Journal Of Education, Psychology and ounseling 2(1), 1-12. 
Marpaung, J. (2016). Kurangnya Kontrol Diri Siswa di Lingkungan SMK Negeri 2 Batam. JURNAL DIMENSI, 5(3), 1-7. https://doi.org/10.33373/dms.v5i3.60

Marwoto, M. (2014). Strategi Guru Sejarah dalam Meningkatkan Minat Belajar Siswa pada Mata Pelajaran Sejarah di Sman 10 Pekanbaru. Lentera: Jurnal Ilmu-Ilmu Sejarah, Budaya dan Sosial, 5(14), 26-31.

Muhyiddin, M. (2020). Covid-19, New Normal, dan Perencanaan Pembangunan di Indonesia. The Indonesian Journal of Development Planning,4(2), 240-252. https://doi.org/10.36574/jpp.v4i2.118

Nafi'ah, I., \& Prasetyo, A. P. B. (2015). Analisis kebiasaan berpikir kritis siswa saat pembelajaran IPA kurikulum 2013 berpendekatan scientific. Journal of Biology Education, 4(1), 53-59. https://doi.org/10.15294/jbe.v4i1.5234

Nezhad, Akbar, S., \& Vahedi, Majid., (2011). The role of educational psychology in teacher education programs. Procedia - Social and Behavioral Sciences, 30(2011). 327-330. https://doi.org/10.1016/j.sbspro.2011.10.064

Nurdianti, S., \& Nurkhin, A. (2016). Peran Cara Belajar dalam Memediasi Pengaruh Internet sebagai Sumber Belajar dan Kepercayaan Diri Terhadap Hasil Belajar Ekonomi. Economic Education Analysis Journal, 5(3), 915-915.

Oktawirawan, D. H. (2020). Faktor pemicu kecemasan siswa dalam melakukan pembelajaran daring di masa pandemi covid-19. Jurnal Ilmiah Universitas Batanghari Jambi, 20(2), 541544. https://doi.org/10.33087/jiubj.v20i2.932

Ramdani, M., \& Apriansyah, D. (2018). Analisis Kemampuan Pemahaman dan Berfikir Kreatif Matematik Siswa Mts pada Materi Bangun Ruang Sisi Datar. Jurnal Cendekia: Jurnal Pendidikan Matematika, 2(2), 1-7. https://doi.org/10.31004/cendekia.v2i2.46

Rusni, R., \& Agustan, A. (2018). Pengaruh Kedisiplinan Belajar Terhadap Hasil Belajar Matematika Siswa di Sekolah Dasar. JRPD (Jurnal Riset Pendidikan Dasar), 1(1), 1-9. https://doi.org/10.26618/jrpd.v1i1.1233

Rozaini, N., \& Anti, S. D. (2017). Pengaruh Motivasi Belajar dan Kepercayaan Diri Siswa Terhadap Prestasi Belajar. NIAGAWAN, 6(2), 54-59. https://doi.org/10.24114/niaga.v6i2.8335

Sabran, S., \& Sabara, E. (2019). Keefektifan Google Classroom sebagai Media Pembelajaran. Seminar Nasional LP2M UNM.

Siregar \& Nurdiana. (2017). Psikologi dan Pembelajaran Matematika. REKOGNISI, 2(1), 7082. https://doi.org/10.31943/mathline.v1i2.27

Sundari, H., \& Leonard, L. (2020). Exploring Needs of Academic Writing Course for LMS in the New Normal. JTP-Jurnal Teknologi Pendidikan, 22(3), 140-150.

Supardi, S. U., Leonard, L., Suhendri, H., \& Rismurdiyati, R. (2015). Pengaruh media pembelajaran dan minat belajar terhadap hasil belajar fisika. Formatif: Jurnal Ilmiah Pendidikan MIPA, 2(1). http://dx.doi.org/10.30998/formatif.v2i1.86

Syarifudin, B. (2010). Panduan TA Keperawatan dan Kebidanan Dengan SPSS. Yogyakarta: Grafindo Litera Media.

Supriatna, E. (2020). Wabah Corona Virus Disease (Covid 19) dalam Pandangan Islam'. Salam: Jurnal Sosial dan Budaya Syar-I, 7(6). https://doi.org/10.15408/sjsbs.v7i6.15247

Tresnawati, T., Hidayat, W., \& Rohaeti, E. E. (2017). Kemampuan Berpikir Kritis Matematis dan Kepercayaan Diri Siswa SMA. Symmetry: Pasundan Journal of Research in Mathematics Learning and Education, 2(2), 39-45. https://doi.org/10.23969/symmetry.v2i2.616 
Wahyuni, S. (2014). Hubungan antara kepercayaan diri dengan kecemasan berbicara di depan umum pada mahasiswa psikologi. Ejournal Psikologi, 2(1), 50-64. https://doi.org/10.33024/jpm.v2i1.2430

Werdayanti, A. (2008). Pengaruh Kompetensi Guru dalam Proses Belajar Mengajar di Kelas dan Fasilitas Guru Terhadap Motivasi Belajar Siswa. Dinamika Pendidikan, 3(1), 79-92. https://doi.org/10.15294/dp.v3i1.434

Wibawa, I. S., (2013). Tingkat Kecerdasan Emosional Siswa yang Mengikuti Ekstrakulikuler Olahraga dan yang Tidak Mengikuti Ekstrakulikuler Olahraga Di SMK PGRI Sentolo. Fakultas Ilmu Keolahragaan Universitas Negeri Yogyakarya. SKRIPSI

Wirantasa, U. (2017). Pengaruh kedisiplinan siswa terhadap prestasi belajar Matematika. Formatif: Jurnal Ilmiah Pendidikan MIPA, 7(1), 83-95. https://doi.org/10.30998/formatif.v7i1.1272

Wiryanto. (2020). Proses Pembelajaran Matematika Di Sekolah Dasar Di Tengah Pandemi Covid-19. Jurnal Pendidikan dan Hasil Penelitian, 6(2), 1-8. http://dx.doi.org/10.26740/jrpd.v6n2.p125-132

Yunus, N. R., \& Rezki, A. (2020). Kebijakan Pemberlakuan Lock Down Sebagai Antisipasi Penyebaran Corona Virus Covid-19. Salam: Jurnal Sosial dan Budaya Syar-i, 7(3), 227238. https://doi.org/10.15408/sjsbs.v7i3.15083 